\title{
Perbedaan cash holding pada perusahaan Dengan leverage tinggi dan rendah
}

\author{
Anggita Langgeng Wijaya \\ Pendidikan Ekonomi Akuntansi IKIP PGRI Madiun \\ Jl. Setia Budi 85 Madiun, Jawa Timur 63118 \\ Email: tugas2q@gmail.com
}

\begin{abstract}
This research tests the difference of cash holdings based on high and low corporate leverage for a sample of manufacturing company enlisted in Indonesian Stock Exchange over the period 2005-2007. Population of this research is all of manufacturing company at Indonesian Stock Exchange. Sampling methods use purposive sampling method. Hypothesis test use MannWhitney analysis. The results show that there are significance difference of cash holding among high leverage and low leverage firm. Firm with high leverage hold lower level of corporate cash holdings.
\end{abstract}

Keyword: cash holding, dummy, leverage.

\section{Pendahuluan}

Ginglinger dan Saddour (2007) menyatakan bahwa penentuan tingkat cash holding perusahaan merupakan salah satu keputusan keuangan penting yang harus diambil oleh seorang manajer keuangan. Cash holding dapat digunakan untuk beberapa hal, antara lain dibagikan kepada pemegang saham berupa dividen, melakukan pembelian kembali saham, melakukan investasi atau menyimpannya untuk kepentingan perusahaan di masa depan. Perusahaan harus dapat menjaga kas yang dimiliki pada tingkat yang optimal karena menahan kas terlalu besar dalam aktiva adalah hal yang tidak produktif dan memerlukan biaya yang tinggi. Swanson (2006) berpendapat bahwa tujuan perusahaan memiliki cash holding antara lain membayar hutang, membiayai kesempatan investasi yang menguntungkan serta sebagai cadangan apabila terdapat unknown hazards.

Menurut Teruel et al. (2009), cash holding merupakan rasio yang membandingkan antara jumlah kas dan setara kas yang dimiliki perusahaan dengan jumlah aktiva perusahaan secara keseluruhan. Koshio (2003) mengungkapkan bahwa dalam pasar modal yang sempurna, cash holding merupakan hal yang tidak relevan. Hal ini dikarenakan perusahaan akan secara mudah memperoleh dana dari pasar eksternal. Namun pada pasar modal yang tidak sempurna, cash holding adalah hal yang penting karena berkaitan dengan ketersediaan kas untuk membiayai berbagai aktivitas perusahaan.

Wenyao (2007) menyatakan bahwa manajer yang hendak meningkatkan kesejahteraan pemegang saham, harus merancang cash holding perusahaan pada tingkat yang tepat antara keuntungan dan biaya yang harus ditanggung oleh perusahaan. Menurut Wenyao (2007), leverage adalah salah satu faktor yang menentukan cash holding perusahaan. Leverage merupakan rasio yang membandingkan antara total hutang dengan total aktiva perusahaan. Jika leverage dianggap sebagai kemampuan perusahaan dalam menerbitkan hutang maka pengaruh levarage terhadap cash holding adalah negatif. Namun, jika leverage yang besar dianggap sebagai potensi kebangkrutan yang terjadi karena tingginya masalah keagenan dari hutang maka pengaruh levarage terhadap cash holding adalah positif.

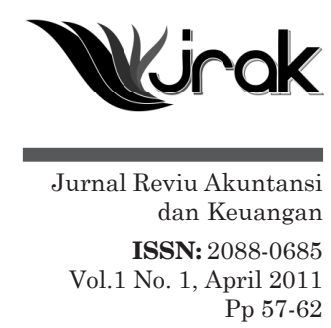




\section{Perbedaan Cash Holding}

Menurut Teruel et al. (2009), hubungan antara leverage dan cash holding adalah negatif. Hal ini dikarenakan jika perusahaan memiliki akses yang baik ke pasar obligasi, perusahaan dapat menggunakan hutang sebagai substitusi aktiva lancar perusahaan, meskipun sebenarnya perusahaan lebih suka memiliki kas yang tinggi dan hutang yang rendah. Perusahaan dengan hutang yang tinggi akan menggunakan hutang tersebut untuk berinvestasi sehingga jumlah kas yang dipegang menjadi kecil. Hasil penelitian Ozkan dan Ozkan (2004) menunjukkan bukti bahwa jika leverage meningkat maka jumlah cash holding akan menurun.

Guney et al. (2007) melakukan penelitian tentang hubungan antara leverage dan cash holding. Hubungan antara leverage dan cash holding dapat berupa hubungan yang positif maupun negatif. Jika leverege adalah substitusi kas yang dapat digunakan perusahaan untuk melakukan investasi maka hubungan antara leverage dan cash holding adalah negatif. Namun, seiring dengan besarnya jumlah leverage maka perusahaan akan mengakumulasi kas dalam jumlah yang besar untuk mengurangi risiko kesulitan keuangan namun dan kebangkrutan sehingga hubungan antara leverage dan cash holding dapat menjadi positif.

Pertanyaan dalam penelitian ini adalah: apakah terdapat perbedaan cash holding pada perusahaan dengan leverage tinggi dan perusahaan dengan leverage rendah? Teruel et al. (2009) menyatakan bahwa leverage berpengaruh negatif terhadap cash holding. Implikasinya adalah perusahaan dengan tingkat leverage yang tinggi akan memiliki cash holding yang lebih rendah. Namun, apabila mengacu pada Guney et al. (2007), leverage berpengaruh positif terhadap cash holding. Implikasinya adalah perusahaan yang memiliki leverage yang tinggi akan memiliki cash holding dalam jumlah yang tinggi pula. Untuk membuktikan hal tersebut, maka perlu dilakukan analisis perbedaan cash holding pada perusahaan dengan tingkat leverage tinggi dan leverage rendah.

Ozkan dan Ozkan (2004) melakukan investigasi empiris tentang cash holding perusahaan-perusahaan di Inggris. Data dalam penelitian diambil dari Datastream Database. Salah satu hasil penelitian ini menyatakan bahwa levarage berpengaruh negatif terhadap cash holding perusahaan. Hasil penelitian ini bertentangan dengan hipotesis financial constraint yang diungkapkan oleh Ginglinger dan Saddour (2007) yang menyebutkan bahwa leverage berpengaruh positif terhadap cash holding perusahaan.

Wenyao (2007) menyatakan bahwa jika dipandang bahwa leverage merupakan substitusi akan kebutuhan dana untuk investasi, maka peningkatan leverage akan menyebabkan jumlah cash holding menjadi kecil, sehingga hubungan antara leverage dan cash holding adalah negatif. Namun apabila dilihat dari sisi agency costs of debt dan potensi terjadinya kesulitan keuangan serta kebangkrutan maka hubungan antara hubungan antara leverage dan cash holding adalah positif. Perusahaan dengan hutang yang besar akan cenderung memiliki cash holding yang besar untuk melunasi hutang tersebut (Wenyao, 2007). Hasil penelitian ini mendukung penelitian Guney et al. (2007) yang menyatakan bahwa leverage berpengaruh positif terhadap cash holding perusahaan.

Opler et al. (1999) menemukan adanya hubungan yang positif antara leverage dan cash holding perusahaan. Pendapat lain, Couderc (2005) mengungkapkan bahwa pengaruh leverage terhadap cash holding perusahaan adalah negatif. Leverage yang besar menunjukkan kemudahan akses ke pasar modal sehingga perusahaan bisa menahan kas dalam jumlah yang kecil. Saddour (2006) menyatakan bahwa pengaruh leverage terhadap cash holding adalah negatif. Hal ini dikarenakan hutang dapat digunakan untuk membiayai berbagai investasi perusahaan. Menurut Saddour (2006), hutang adalah substitusi kas yang dapat digunakan membiayai investasi sehingga jika hutang besar maka perusahaan dapat menahan sedikit kas. Pendapat ini konsisten dengan penelitian Couderc (2005).

Jani et al. (2004) menjelaskan bahwa hubungan antara leverage dan cash holding dapat dijelaskan dari dua sisi teori yaitu TOT dan POT theory. Dari sisi pandang trade off theory (TOT), saldo cash holding yang terlalu tinggi merupakan hal yang tidak produktif bagi perusahaan. Leverage merupakan substitusi kas 
yang dapat digunakan untuk membiayai berbagai kegiatan perusahaan sehingga hubungan antara cash dan leverage diharapkan negatif. Ozkan dan Ozkan (2004) menyatakan bahwa hutang akan mengurangi isu moral hazard. Hutang dianggap lebih fleksibel dan mudah untuk dinegosiasi ulang apabila terdapat kesulitan bagi perusahaan. Hutang adalah substitusi dari cash holding sehingga diharapkan hubungan antara leverage dan cash holding adalah negatif (Ozkan dan Ozkan, 2004).

Dari sisi pandang pecking order theory (POT), Jani et al. (2004) menjelaskan bahwa hubungan antara cash holding dan leverage adalah positif. Perusahaan dengan sumber daya keuangan yang cukup akan menggunakan kas untuk aktivitas operasional perusahaan. Jika sumber daya internal tidak cukup maka perusahaan akan menggunakan hutang. Perusahaan akan berusaha untuk membentuk hutang yang optimal. Ketika hutang jatuh tempo maka perusahaan membutuhkan kas untuk melunasi hutang tersebut sehingga perusahaan dengan jumlah leverage yang tinggi akan membutuhkan kas dalam jumlah yang besar. Hubungan antara leverage dan cash holding adalah positif (Jani et al., 2004).

Berdasar beberapa penelitian di atas, terdapat dua pendapat yang bertentangan. Pendapat pertama menyatakan bahwa menyatakan bahwa hubungan antara leverage dan cash holding adalah positif sedangkan pendapat kedua menyatakan hubungan antara leverage dan cash holding adalah negatif. Apabila leverage berpengaruh positif terhadap cash holding maka perusahaan dengan leverage besar akan memiliki cash holding yang besar pula. Sebaliknya, jika leverage berpengaruh negatif terhadap cash holding maka perusahaan dengan leverage besar akan menahan kas dalam jumlah yang kecil. Untuk membuktikan hal tersebut, peneliti akan membagi levarage ke dalam dua kategori yaitu perusahaan dengan leverage tinggi dan perusahaan dengan leverage rendah, kemudian dilakukan uji beda cash holding berdasar dua kategori leverage tersebut.

Berdasar pembahasan di atas, maka hipotesis yang diajukan dalam penelitian ini adalah sebagai berikut.

$\mathrm{H}_{1}$ : terdapat perbedaan cash holding yang signifikan antara perusahaan dengan leverage tinggi dan perusahaan dengan leverage rendah.

\section{Metode}

\section{Data, Populasi dan Sampel}

Penelitian ini merupakan penelitian empiris dengan tipe penelitian hypothesis testing. Melalui penelitian ini peneliti akan menguji perbedaan cash holding pada perusahaan dengan leverage tinggi dan perusahaan dengan leverage rendah. Populasi dalam penelitian ini seluruh perusahaan manufaktur yang terdaftar di Bursa Efek Indonesia. Penelitian ini menggunakan data sekunder dari laporan keuangan perusahaan manufaktur tahun 2005-2007. Data dalam penelitian ini diambil dengan metoda purposive sampling. Dari hasil pengumpulan data diperoleh sampel 112 perusahaan per tahun sehingga jumlah observasi selama tiga tahun sebanyak 336 perusahaan.

\section{Definisi Operasional Variabel}

Variabel dalam penelitian ini adalah cash holding dan leverage. Menurut Teruel et al. (2009), cash holding adalah rasio keuangan yang membandingkan jumlah kas perusahaan dengan jumlah aktiva perusahaan diluar kas. Mengacu pada Teruel et al. (2009), cash holding dinotasikan dengan rumus sebagai berikut.

Cash holding $=\frac{\text { kas }+ \text { setara kas }}{\text { Total aktiva }- \text { kas }}$

Variabel kedua dalam penelitian ini adalah leverage. Leverage merupakan rasio keuangan perusahaan yang membandingkan antara total hutang dengan 


\section{Perbedaan Cash Holding}

Tabel 1

Statistik Deskriptif

Tabel 2

Rata-rata Rangking total aktiva perusahaan. Mengacu pada panelitian Wenyao (2007), leverage dinotasikan dengan rumus sebagai berikut.

\section{Leverage $=$}

Dari rasio leverage di atas dihitung nilai median untuk membentuk variabel dummy leverage. Nilai rasio leverage di atas nilai median menunjukkan perusahaan dengan laverage besar. Nilai leverage di bawah median menunjukkan perusahaan dengan leverage kecil. Kemudian dibentuk variabel dummy yaitu nilai 1 untuk perusahaan dengan leverage tinggi dan 0 untuk perusahaan dengan leverage rendah.

\section{Metoda Analisis Data}

Hipotesis dalam penelitian ini diuji dengan uji beda. Alat analisis yang digunakan adalah uji Mann-Whitney. Melalui penelitian ini akan diuji apakah terdapat perbedaan cash holding pada perusahaan dengan leverage besar dan leverage kecil. Menurut Santoso (2006) jika nilai p di bawah 0.05 berarti terdapat perbedaan yang signifikan antara dua kelompok yang diuji.

\section{Hasil dan Pembahasan}

\section{Statistik Deskriptif}

Penelitian ini bertujuan menguji perbedaan cash holding pada perusahaan dengan leverage besar dan leverage kecil. Hasil uji statistik deskriptif untuk masing-masing variabel penelitian tersaji pada tabel berikut ini.

\begin{tabular}{lccccc}
\hline & N & Minimum & Maximum & Mean & Std. Deviation \\
\hline CASH & 336 & 0.00 & 0.86 & 0.09 & 0.12 \\
DUMLEV & 336 & 0.00 & 1.00 & 0.49 & 0.50 \\
Valid N & 336 & & & & \\
(listwise) & & & & & \\
\hline
\end{tabular}

Sumber: Hasil Pengolahan Data

Keterangan: $\mathrm{CASH}=$ cash holdings, $\mathrm{DUMLEV}=$ dummy variabel leverage, nilai 1 untuk perusahaan dengan leverage tinggi dan nilai 0 untuk perusahaan dengan leverage rendah.

Dari tabel di atas diketahui bahwa jumlah observasi selama perioda 20052007 sebanyak 336 perusahaan. Variabel cash holding memiliki nilai minimum 0.00 dengan nilai maksimum sebesar 0.86 . Nilai rata-rata cash holding sebesar 0.09 dengan standar deviasi sebesar 0.12 . Variabel dummy leverage memiliki nilai minimum 0 dengan nilai maksimum 1 . Nilai rata-rata dummy leverage sebesar 0.49 dengan standar deviasi sebesar 0.50 .

\section{Uji Hipotesis}

Hipotesis dalam penelitian ini diuji dengan menggunakan uji beda MannWhitney. Hasil uji hipotesis tersaji pada tabel berikut ini.

\begin{tabular}{llccc}
\hline & DUMLEV & N & Mean Rank & Sum of Ranks \\
\hline CASH & leverage rendah & 173 & 194.84 & 33707.00 \\
& leverage tinggi & 163 & 140.55 & 22909.00 \\
& Total & 336 & & \\
\hline
\end{tabular}

Sumber: Hasil Pengolahan Data

Tabel 2 menunjukkan bahwa sebanyak 173 perusahaan sampel masuk dalam kategori perusahaan dengan leverage rendah dan 163 perusahaan sampel masuk dalam kategori perusahaan dengan leverage tinggi. Mean rank dari perusahaan dengan leverage rendah sebesar 194.84 sedangkan perusahaan dengan leverage tinggi memiliki mean rank sebesar 140.55. Perusahaan dengan leverage rendah 
memiliki mean rank yang lebih besar jika dibandingkan dengan perusahaan dengan leverage tinggi. Untuk mengetahui apakah perbedaan tersebut signifikan atau tidak, maka dilakukan uji beda Mann-Whitney. Hasil uji beda Mann-Whitney tersaji pada tabel berikut ini.

Hasil uji beda Mann-Whitney menunjukkan nilai Z sebesar -5.12 dengan nilai p sebesar 0.00. Pengujian memberikan hasil yang signifikan sehingga dapat disimpulkan bahwa terdapat perbedaan cash holding yang signifikan antara perusahaan dengan leverage tinggi dengan perusahaan dengan leverage rendah. $\mathbf{H}_{1}$

\begin{tabular}{lr}
\hline & CASH \\
\hline Mann-Whitney U & 9543.00 \\
Wilcoxon W & 22909.00 \\
Z & -5.12 \\
Asymp. Sig. (2-tailed) & 0.000 \\
\hline
\end{tabular}

Sumber: Hasil Pengolahan Data

di dukung. Hasil penelitian ini membuktikan bahwa perusahaan dengan leverage yang besar akan cenderung memiliki tingkat cash holding yang kecil. Menurut Couderc (2005) dan Teruel et al. (2009), hutang adalah substitusi kas untuk membiayai kegiatan investasi perusahaan. Perusahaan dengan leverage yang besar, tidak perlu menahan kas dalam jumlah yang besar karena kemudahan perusahaan memperoleh sumber pendanaan dari hutang yang dapat digunakan untuk membiayai investasi. Ginglinger dan Saddour (2007) menyebutkan bahwa jumlah kas yang berlebih dalam neraca adalah hal yang tidak produktif bagi perusahaan. Hal ini menyebabkan perusahaan dengan leverage yang besar akan cenderung untuk memiliki cash holding dalam jumlah yang kecil dengan tunjuan menjaga saldo cash holding pada nilai yang optimal (Jani et al., 2004). Hasil penelitian ini mendukung hasil penelitian Ozkan dan Ozkan (2004), Couderc (2005), Saddour (2006) dan Teruel et al. (2009) yang menyatakan bahwa hubungan antara leverage dan cash holding adalah negatif. Namun hasil penelitian ini tidak mendukung pendapat Guney et al. (2007) yang menyatakan bahwa hubungan antara leverage dan cash holding adalah positif.

Implikasi hasil penelitian ini adalah perusahaan dengan leverage yang besar memiliki kecenderungan untuk menahan kas dalam jumlah yang kecil. Saddour (2006) menyatakan bahwa leverage yang besar menunjukkan kemudahan akses perusahaan ke pasar modal yang menyebabkan perusahaan dapat melakukan investasi dengan sumber pendanaan yang berasal dari hutang, sehingga semakin besar hutang perusahaan cukup menahan kas dalam jumlah yang kecil. Couderc (2005) menjelaskan bahwa leverage yang besar menunjukkan kekuatan perusahaan menuju akses sumber pembiayaan perusahaan. Perusahaan yang memiliki dukungan hutang yang kuat dalam sumber pendaaannya, tidak perlu memegang kas dalam jumlah besar karena hutang dapat menjadi substitusi bagi kas perusahaan untuk membiayai berbagai aktivitas perusahaan (Couderc, 2005).

\section{Simpulan}

Penelitian ini bertujuan menguji perbedaan cash holding pada perusahaan dengan leverage tinggi dan leverage rendah pada perusahaan manufaktur yang terdaftar di Bursa Efek Indonesia tahun 2005-2007. Berdasar hasil analisis dan pembahasan dapat disimpulkan bahwa terdapat perbedaan cash holding yang signifikan antara perusahaan dengan leverage tinggi dengan perusahaan dengan leverage rendah. Perusahaan dengan leverage yang tinggi memiliki kemudahan akses ke pasar modal (Couderc, 2005). Selain itu, leverage merupakan subtitusi kas dalam melakukan investasi sehingga jika leverage tinggi perusahaan dapat menahan kas dalam jumlah yang rendah (Couderc, 2005). 


\section{Perbedaan Cash Holding}

62
Keterbatasan penelitian ini adalah perioda penelitian yang relatif pendek serta sampel hanya menggunakan perusahaan dengan jenis industri manufaktur.

Penelitian selanjutnya disarankan untuk menguji faktor lain yang diduga berpengaruh terhadap cash holding seperti corporate governance. Penelitian selanjutnya disarankan untuk memperpanjang perioda penelitian dan mengambil sampel diluar perusahaan manufaktur.

\section{Daftar Pustaka}

Couderc, Nicolas. 2005. "Corporate Cash Holdings: Financial Determinants and Consequences". Available on line at http:// www.univ-orleans.fr. Diakses tanggal 21 Maret 2010.

Ginglinger, Edith; dan Khaoula Saddour. 2007. "Cash Holdings, Corporate Governance and Financial Constraints". Available on line at http:// www.ssrn.com. Diakses tanggal 21 Maret 2010.

Guney, Yilmaz; Aydin Ozkan; dan Neslihan Ozkan. 2007. "International evidence on the non-linear impact of leverage on corporate cash holdings". Journal of Multinational Financial Management. Vol. 17 Issue 1 (February): 1-23.

Jani, Elion; Martin Hoesli; dan Andre Bender. 2004. "Corporate Cash Holdings and Agency Conflicts". Available on line at http:// www.ssrn.com. Diakses tanggal 9 Oktober 2010.

Koshio, Senichiro. 2003. "The Determinants of Corporate Cash Holdings in Brazil". Research Plan for PhD Dissertation Fundação Getúlio Vargas - EAESP, Brazil.

Opler, T., L. Pinkowitz, R. Stulz, and R. Williamson, 1999. "The determinants and implications of corporate cash holdings". Journal of Financial Economics. Vol. 52 Issue 1 (April): 3-46.

Ozkan, Aydin; dan Neslihan Ozkan. 2004. "Corporate cash holdings: An empirical investigation of UK companies". Journal of Banking and Finance. Vol. 28 Issue 9 (September): 2103-2134.

Saddour, Khaoula. 2006. "The Determinants and the Value of Cash Holdings: Evi" dence from French firms". Available on line at http:// www.dauphine.fr. Diakses tanggal 1 Desember 2010.

Santoso, Singgih. 2006. Menggunakan SPSS untuk Statistik Non Parametrik. PT. Elex Media Komputindo: Jakarta.

Swanson, Zane L. 2006. "Impact of Cash Holdings on Investment Value". Available on line at http:// www.ssrn.com. Diakses tanggal 9 Oktober 2010.

Teruel, Pedro J. García; Pedro Martínez Solano; dan Juan Pedro Sánchez Ballesta. 2009. "Accruals quality and corporate cash holdings". Journal compilation Accounting and Finance. Vol. 49 Issue 1 (March): 95-115.

Wenyao, Li. 2007. "The Determinants of Cash Holdings: Evidence from Chinese Listed Companies". Available on line at http:// www.seiofbluemountain.com. Diakses tanggal 2 Juli 2010. 